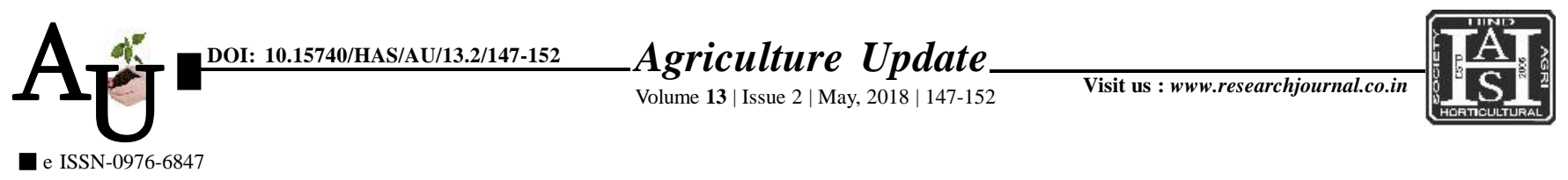

\title{
Research Article: Study on knowledge level of farmers about chilli cultivation
}

\begin{tabular}{l} 
Article Chronicle: \\
\hline Received : \\
24.02.2018; \\
Revised : \\
19.03.2018; \\
Accepted : \\
05.04.2018
\end{tabular}

\begin{abstract}
Received :
24.02.2018,

Revised :

Accepted :

05.04.2018
\end{abstract}

\section{KeY Words :}

Knowledge, Ex-postfacto, Adoption, Chilli production

technology, Improved cultivation practices

\section{Venkata Reddy, P.K. Wakle and N.R. Koshti}

SUMMARY : The study was conducted in Bhiwapur Panchyat Samiti of Nagpur districtat Maharashtra state in 2016-2017, so as to find out the level of knowledge about improved cultivation practices and adoption of recommended cultivation practices of chilli by the farmers. From each selected village fifteen respondents were purposivelyselected for the study. Thus, a total of 150 farmers were selected for the study. The "Ex-post-facto" research design was used for the study. Data were recorded through interview schedule and were analyzed by using appropriate statistical methods. The study revealed that the maximum 53.34 per cent respondents had medium level of overall knowledge about chilli production technology. In case of reasons for decline of chilli crop in research area were 95 per cent lack of Churdamurda resistant varieties of chilli, 93.33 per cent delayed transplanting because of no rains, 88 per cent vagaries in monsoon, and 80.00 per cen thigh cost of insecticides, fertilizers and inputs are the major factors associated for decline the area under chilli cultivation.

How to cite this article : Reddy, I. Venkata, Wakle, P.K. and Koshti, N.R. (2018). Study on knowledge level of farmers about chilli cultivation. Agric. Update, 13(2): 147-152; DOI : 10.15740/HAS/AU/13.2/147-152. Copyright@2018: Hind Agri-Horticultural Society.
Author for correspondence :

\section{Venkata Reddy}

Department of

Agricultural Extension,

Agricultural College,

Bapatla (A.P.) India

Email:bobbyreddyagrico119

@gmail.com

See end of the article for

authors' affiliations 